\title{
TINGKAT KEPADATAN JENTIK NYAMUK AEDES AEGYPTI SEBAGAI VEKTOR DEMAM BERDARAH DENGUE (DBD) DI WILAYAH KERJA UNIT PELAKSANA TEKNIS KESMAS BLAHBATUH I TAHUN 2018
}

\author{
Anak Agung Istri Inten', I Nyoman Purna ${ }^{2}$, Nengah Notes
}

\begin{abstract}
Dengue hemorrhagic fever is an infectious disease caused by dengue virus and is transmitted by aedes aegypty mosquitoes. Puskesmas Blahbatuh I in 2016 is included in the top 10 cases of Dengue Fever which is 195 cases (Dinkes, 2017). The purpose of this research is to know the level of density of mosquito larvae Aedes aegypty as dengue fever vector in the working area UPT Kesmas Blahbatuh I Year 2018. Type of research used in this research is descriptive research type with cross sectional approach. This research was conducted in working area of UPT Kesmas Blahbatuh I which consists of five villages namely Medahan Village, Keramas Village, Pering Village, Belega Village and Bona Village.Obtained HI value (House of Indeks) : $16 \%$, CI (Container Indeks): $8 \%$, BI (Bruteu Indeks): $16 \%$, ABJ (Larva Free Rate) : $84 \%$ and DF (Density Figure) : 3 as a medium density. The Prevention is do PSN or eradiation of mosquito breeding. The conclution is the area of UPT Kesmas Blahbatuh I has been moderate the mosquito larvae density.
\end{abstract}

\section{Keyword : Density Figure, Larva Indeks}

Demam berdarah dengue di 9 kabupaten dimana salah satunya adalah penyakit menular yang adalah Kabupaten Gianyar Provinsi disebabkan oleh virus Dengue dan ditularkan oleh nyamuk aedes aegypti. Penyakit Demam Berdarah Dengue Merupakan masalah kesehatan masyarakat yang serius didunia khususnya di Indonesia yang terletak di katulistiwa.

Berdasarkan data Direktorat Pengendalian Penyakit Tular Vektor dan Zoonosis Kementerian Kesehatan menyebutkan hinggal akhir Januari tahun 2016,(1) kejadian luar biasa (KLB) penyakit DBD dilaporkan ada Bali. Berdasarkan data pada bulan Januari 2015 kasus DBD di Kabupaten Gianyar sebanyak 216 kasus, jumlah ini meningkat 52 persen dari pada kasus yang terjadi pada bulan januari 2014 sebanyak 142 kasus. Berdasarkan pola 10 bersar penyakit pada pasien Rawat inap di RSU di kabupaten Gianyar pada tahun 2016, penyakit demam berdarah adalah penyakit tertinggi yang di rawat dengan jumlah sebesar 2164 kasus (2) 
UPT Kesmas Blahbatuh I penelitian.(3) Nilai yang didapat di adalah salah satu Puskesmas yang terletak dikabupaten Gianyar yang memiliki wilayah kerja yaitu masing-masing variabel dibandingkan dengan kategori berdasarkan Larva Indeks.

sebanyak lima desa diantaranya Desa Medahan, Desa Keramas, Desa Pering, Desa Belega dan Desa Bona. Jumlah kasus DBD di Puskesmas Blahbatuh I tahun 2016 termasuk kedalam 10 besar kasus tertinggi di Kabupaten Gianyar yaitu sebanyak 195 Kasus (Dinkes, 2007). Tujuan dari penelitian ini adalah untuk Mengetahui Tingkat Kepadatan Jentik Nyamuk Aedes Aegypty sebagai Vektor Demam Berdarah Dengue di Wilayah Kerja UPT Kesmas Blahbatuh I Tahun 2018.

\section{Metode Penelitian}

Jenis penelitian yang digunakan dalam penelitian ini adalah jenis penelitian deskriptif dengan pendekatan cross sectional. Penelitian ini dilakukan di wilayah kerja UPT Kesmas Blahbatuh I yang terdiri dari lima desa yaitu Desa Medahan, Desa Keramas, Desa Pering, Desa Belega dan Desa Bona. Analisis data dalam penelitian ini menggunakan metode analisis univariat bertujuan untuk menjelaskan atau mendeskripsikan karakteristik setiap variabel

\section{Hasil dan Pembahasan}

\section{A. Gambaran Umum UPT Kesmas} Blahbatuh I

Unit Pelaksana Teknis Kesehatan Masyarakat (UPT Kesmas) Blahbatuh I merupakan salah satu dari dua UPT Kesmas yang berada di Kecamatan Blahbatuh dengan luas wilayah kerja 19,65 km². Batas wilayah kerja UPT Kesmas Blahbatuh I diantaranya :

- Sebelah Utara : Desa Abianbase

- Sebelah : Pantai Masceti

- Sebelah Timur : Desa Lebih

- Sebelah Barat: Desa Blahbatuh

Topografi Wilayah UPT Kesmas Blahbatuh I sebagian besar merupakan dataran rendah yang terbentang dari ke Utara. Wilayah Wilayah UPT Kesmas Blahbatuh I secara umum beriklim laut tropis yang dipengaruhi oleh angin musim. Sebagai daerah tropis wilayah Kerja UPT Kesmas Blahbatuh I yang meliputi 5 desa memiliki musim kemarau dan musim hujan yang diselingi oleh musim panca roba, 
B. Tingkat Kepadatan Jentik Nyamuk Aedes Aegypty Berdasarkan Indikator House Indeks (HI).

Tabel 1

Retribusi Jumlah Rumah Positif Jentik di Setiap Desa di Wilayah UPT Kesmas Blahbatuh I

\begin{tabular}{lcc}
\hline \multicolumn{1}{c}{ Nama Desa } & Jumlah Rumah Positif Jentik & Jumlah KK yang Diperiksa \\
\hline \multicolumn{1}{c}{ Desa Medahan } & 2 & 3 \\
Desa Keramas & 3 & 20 \\
Desa Pering & 4 & 29 \\
Desa Bona & 4 & 23 \\
Desa Belega & 3 & 13 \\
\hline \multicolumn{1}{c}{ Total } & 2 & 15 \\
\hline
\end{tabular}

Berdasarkan tabel diketahui bahwa Jumlah Rumah Positif Jentik di wilayah UPT Kesmas Blahbatuh I adalah 16 rumah dimana desa yang paling banyak terdapat jentik adalah di desa Keramas dan Pering yaitu masing-masing 4 rumah.

Berikut adalah perhitungan nilai $\%$.

House Indeks (HI) di Wilayah UPT

Kesmas Blahbatuh I :

C. Menilai Tingkat Kepadatan Jentik Nyamuk Aedes Aegypty Berdasarkan Indikator Container Indeks (CI).

Tabel 2

Distribusi Jumlah Kontainer yang Positif Jentik di Wilayah Kerja UPT Kesmas Blahbatuh I

\begin{tabular}{lcc}
\hline Nama Desa & $\begin{array}{c}\text { Jumlah Kontainer } \\
\text { Positif Jentik }\end{array}$ & $\begin{array}{c}\text { Jumlah Kontainer } \\
\text { Yang Diperiksa }\end{array}$ \\
\hline \multicolumn{1}{c}{1} & 2 & 3 \\
\hline Desa Medahan & 3 & 45 \\
Desa Keramas & 4 & 47 \\
Desa Pering & 4 & 56 \\
Desa Bona & 3 & 24 \\
Desa Belega & 2 & 29 \\
\hline \multicolumn{1}{c}{ Total } & 16 & 201 \\
\hline
\end{tabular}


Berdasarkan tabel diketahui jumlah container yang positif jentik adalah 16 container dari 201 kontainer yang diperiksa. Berikut adalah perhitungan container indeks di wilayah kerja UPT Kesmas Blahbatuh I :

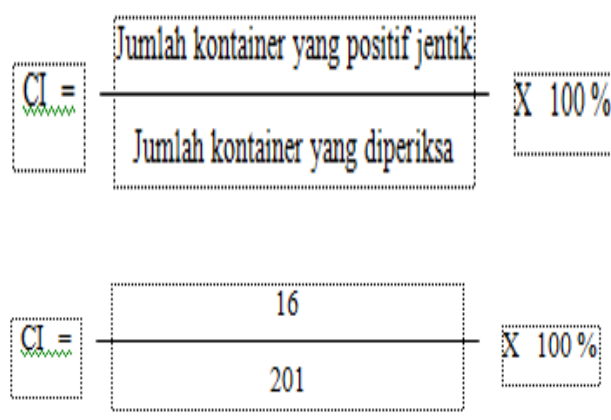

\section{$\mathrm{CI}=7,96 \%=8 \%$}

Diketahui jenis container yang paling banyak didapatkan adalah container Bak Mandi dengan jumlah 115 , Sedangkan untuk container yang paling sering didapatkan positif jentik adalah Bak Mandi dan Bak Dapur.

D. Menilai Tingkat Kepadatan Jentik Nyamuk Aedes Aegypty Berdasarkan Indikator Bruteu Indeks $(B I)$.

Untuk nilai bruteu indeks didapatkan dengan perhitungan dibawah ini :

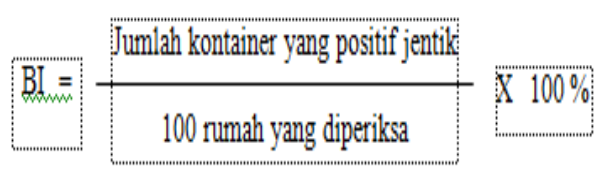

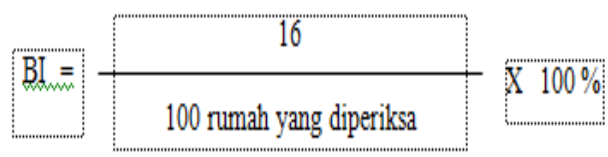

$\mathrm{BI}=16 \%$

Jadi nilai bruteu indeks di Wilayah Kerja UPT Kesmas Blahbatuh I adalah $16 \%$.

1. Angka Bebas Jentik (ABJ)

$$
\begin{aligned}
A B J & =100-H I \\
& =100-16 \% \\
& =84 \%
\end{aligned}
$$

Didapatkan angka bebas jentik di wilayah kerja UPT Kesmas Blahbatuh I adalah 84\%. Hal ini termasuk Wilayah Beresiko.

E. Menilai Angka Density Figure $(D F)$ di Wilayah Kerja UPT Kesmas Blahbatuh I.

Berdasarkan data yang telah didapatkan, dimana nilai House Indeks (HI) : $16 \%$, Nilai Container Indeks (CI) : $8 \%$, nilai Bruteu Indeks (BI) : 16, maka hasil tersebut dibandingkan dengan tabel 1 larva indeks didapatkan nilai Density Figure / Tingkat Kepadatan Jentik Nyamuk di Wilayah Kerja UPT Kesmas Blahbatuh I berada pada 
nilai 3 yang berarti wilayah memiliki Kepadatan Sedang.

Tabel 3

Larva Indeks

\begin{tabular}{|c|c|c|c|}
\hline $\begin{array}{c}\text { Density figure } \\
\text { (DF) }\end{array}$ & House Index (HI) & $\begin{array}{c}\text { Container Index } \\
\text { (CI) }\end{array}$ & $\begin{array}{c}\text { Breteau Index } \\
\text { (BI) }\end{array}$ \\
\hline 1 & $1-3$ & $1-2$ & $1-4$ \\
\hline 2 & $4-7$ & $3-5$ & $5-9$ \\
\hline 3 & $8-17$ & $6-9$ & $10-19$ \\
\hline 4 & $18-28$ & $10-14$ & $20-34$ \\
\hline 5 & $29-37$ & $15-20$ & $35-49$ \\
\hline 6 & $38-49$ & $21-27$ & $50-74$ \\
\hline 7 & $50-59$ & $28-31$ & $75-99$ \\
\hline 8 & $60-76$ & $32-40$ & $100-199$ \\
\hline 9 & $>77$ & $>41$ & $>200$ \\
\hline Sumber. Santoso,y(2011) \\
Keterangan Tabel. \\
DF =1 = kepadatan rendah \\
DF = 2-5 = kepadatan sedang \\
DF = 6-9 = kepadatan tinggi.
\end{tabular}

\section{Pembahasan}

A. Kepadatan Jentik Nyamuk Aedes Aegypty Berdasarkan Indikator House Indeks (HI).

Diketahui bahwa Jumlah Rumah Positif Jentik di wilayah UPT Kesmas Blahbatuh I adalah 16 rumah dimana desa yang paling banyak terdapat jentik adalah di desa Keramas dan Pering yaitu masingmasing 4 rumah.

Letak wilayah serta kepadatan penduduk mempengaruhi keberadaan jentik dimana Demam Berdarah Dengue merupakan penyakit yang disebabkan oleh virus Dengue dan ditularkan oleh vector nyamuk aedes aegypty. Wilayah Puskesmas Blahbatuh I secara umum mempunyai risiko terjangkit penyakit DBD, karena vektor penyebabnya yaitu nyamuk Aedes aegypti tersebar luas di kawasan pemukiman maupun tempat-tempat umum, kecuali wilayah yang terletak pada ketinggian lebih dari 1000 meter di atas permukaan laut. Desa Pering dan Keramas adalah Desa yang memiliki kepadatan penduduk yang tinggi sehingga berpotensi menjadi tempat perkembangbiakan jentik. Untuk mengatasi atau mencegah hal tersebut perlu kita ketahui tempat perindukan vector aedes aegypti. Nyamuk ini suka beristirahat didalam maupun diluar rumah atau ditempat yang gelap. Oleh karena itu disarankan kepada pemilik rumah agar tidak menggantung pakaian yang tidak terpakai karena berpotensi menjadi perindukan nyamik saat mematangkan telurnya.

B. Kepadatan Jentik Nyamuk Aedes Aegypty Berdasarkan Indikator Container Indeks (CI).

Diketahui jumlah container yang positif jentik adalah 16 
container dari 201 kontainer yang diperiksa. Untuk container yang paling sering didapatkan positif jentik adalah Bak Mandi dan Bak Dapur. Berdasarkan tabel, diketahui jenis container yang paling banyak diperiksa adalah container Bak Mandi dengan jumlah 115.

Aedes aegypti merupakan jenis nyamuk yang dapat membawa virus dengue penyebab penyakit demam berdarah. Penyebaran jenis ini sangat luas, meliputi hampir semua daerah tropis di seluruh dunia. Tempat perindukan Aedes aegypti dapat dibedakan atas tempat perindukan sementara, permanen, dan alamiah. Tempat perindukan sementara terdiri dari berbagai macam tempat penampungan air (TPA) yang dapat menampung genangan air bersih. Tempat perindukan permanen adalah TPA untuk keperluan rumah tangga dan tempat perindukan alamiah berupa genangan air pada pohon. (4)

Dari hasil pengamatan jentik didapatkan container yang paling banyak ditemui jentik nyamuk adalah container Bak Mandi dan Bak Dapur, dimana container ini terdapat didalam rumah. Hal ini sama dengan penelitian (5), yang menyatakan bahwa nyamuk Aedes sp. lebih senang hidup di dalam rumah (indoor). Selain kegiatan abatisasi, sebaiknya juga dilakukan kegiatan PSN yang kegiatannya juga membersihkan tempat-tempat tersembunyi yang dapat dijadikan sebagai tempat untuk berkembangbiak bagi nyamuk Aedes sp. seperti kulkas, dispenser, pot bunga dan tempat-tempat tersembunyi lainnya.membersihkan tempat penampungan air yang berada di dapur dan terutama tempat ibadah dirumah atau merajan (Hindu) karena hal ini sangat sering dilupakan oleh pemilik rumah seperti pada tempat tirta dan jun tandeg.

$$
\text { Faktor lingkungan }
$$

memegang peranan penting dalam penularan penyakit karena dapat mempengaruhi perkembangbiakan vektor. Pemutusan mata rantai penularan dapat mencegah terjadinya penularan penyakit, yaitu dengan pengendalian vektor dengan metode yang tepat. Pengendalian vektor selain dengan kegiatan PSN dan abatisasi juga dapat dilakukan dengan cara biologi kontrol, yaitu dengan menggunakan ikan pemakan jentik. 
Menurut penelitian Taviv dalam (Santoso, 2011), salah satu ikan pemakan jentik yang dapat digunakan sebagai biologi kontrol yaitu ikan cupang (Cnenops vittatus).

C. Kepadatan Jentik Nyamuk Aedes Aegypty Berdasarkan Indikator Bruteu Indeks (BI).

Bruteu Indeks merupakan jumlah penampungan air yang positif larva dari rumah yang diperiksa, BI merupakan salah satu indicator yang paling baik untuk memperkirakan kepada vector, karena mengkombinasi antara tempat tinggal dan container. Apabila suatu wilayah mempunyai BI lebih dari $50 \%$, maka mempunyai resiko tinggi untuk terjadinya penularan, sedangkan apabila BI kurang dari $50 \%$ maka wilayah tersebut mempunyai resiko rendah terjadi penularan. Berdasarkan Data didapatkan nilai Bruteu Indeks adalah $16 \%$. Jadi didapatkan wilayah memiliki resiko rendah terhadap terjadinya penularan.

Hal ini harus didukung dengan melakukan pencegahan terhadap penularan adalah dengan melakukan 3 M plus.(6)
D. Angka Bebas Jentik (ABJ) di Wilayah Kerja UPT Kesmas Blahbatuh I.

Didapatkan angka bebas jentik di wilayah kerja UPT Kesmas Blahbatuh I adalah $84 \%$. Hal ini termasuk Wilayah Beresiko karena memiliki nilai $<95 \%$. Larva nyamuk Aedes aegypti mempunyai ciri khas memiliki siphon yang pendek, besar dan berwarna hitam. Larva ini tubuhnya langsing, bergerak sangat lincah, bersifat fototaksis negatif dan pada waktu istirahat membentuk sudut hampir tegak lurus dengan permukaan air. Larva menuju ke permukaan air dalam waktu kira-kira setiap $1 / 2-1$ menit, guna mendapatkan oksigen untuk bernapas. Larva nyamuk Aedes aegypti dapat berkembang selama 6-8 hari Tempat perkembang biakan nyamuk Aedes Aegypty berupa genangan air yang tertampung di suatu tempat atau bejana. Tempat penampungan seharihari termasuk tempayan. Di wilayah kerja UPT Kesmas Blahbatuh I termasuk wilayah yang beresiko. Hal ini didukung dengan jenis tempat penampungan air masyarakat banyak yang permanen, misalnya bak mandi dan bak dapur, dimana pada saat 
survey ditemukan $57,2 \quad \%$ penampungan yang diperiksa merupakan Bak mandi atau bak yang permanen, sehingga jika tidak diperhatikan atau dibersihkan secara rutin jentik akan dengan mudah berkembang. Mengingat wilayah Puskesmas Blahbatuh I secara umum mempunyai risiko terjangkit penyakit DBD, karena vektor penyebabnya yaitu nyamuk Aedes aegypti tersebar luas di kawasan pemukiman maupun tempat-tempat umum, kecuali wilayah yang terletak pada ketinggian lebih dari 1000 meter di atas permukaan laut.

Berdasarkan penjelasan diatas, disarankan bagi masyarakat agar secara rutin melakukan PSN terutama dilingkungan rumah. PSN yang dapat digunakan adalah dengan melakukan 3M Plus yaitu menguras tempat penampungan air, Menutup tempat penampungan air dan Memanfaatkan atau mengubur barang bakas serta plusnya yaitu memelihara ikan predator jentik seperti ikan kepala timah, menggunakan refelent atau lotion anti nyamuk/ obat nyamuk, serta menanam tanaman pengusir nyamuk seperti liligundi, sereh dll disekitar rumah.

E. Angka Density Figure $(D F)$ di Wilayah Kerja UPT Kesmas Blahbatuh I.

Berdasarkan data yang telah didapatkan, dimana nilai House Indeks (HI) : $16 \%$, Nilai Container Indeks (CI) : $8 \%$, nilai Bruteu Indeks (BI) : 16, Setelah dibandingkan dengan tabel Density Figure, tingkat kepadatan jentik nyamuk di Wilayah Kerja UPT Kesmas Blahbatuh I berada pada nilai 3 yang berarti wilayah memiliki Kepadatan Sedang.

Hal ini menunjukan bahwa wilayah kerja UPT Kesmas Blahbatuh I memiliki penularan DBD yang masih potensial didaerahya. Banyak faktor yang menjadikan wilayah UPT Kesmas Blahbatuh I masih dalam kategori kepadatan sedang, diantaranya terdapat 16 rumah yang positif jentik serta ditemukan container yang positif jentik dimana yang paling banyak adalah bak mandi dan bak dapur.

Sebenarnya container tersebut dapat dikendalikan dari jentik dengan cara $3 \mathrm{M}$ Plus serta 
dengan abatisasi atau dengan cara biologi yaitu dengan memelihara ikan predator jentik. Kepadatan jentik dapat dikendalikan dengan pengendalian populasi aedes aegypty. Salah satu yang dapat dilakukan adalah meningkatkan kegiatan PSN atau Pemberantasan Sarang Nyamuk. Hal ini diperkuat dengan beberapa hasil penelitian yang mendukung dimana PSN dapat menurunkan kepadatan jentik sebagai vector DBD (7) . Mengingat kegiatan PSN merupakan kegiatan yang sangat penting sebagai upaya pencegahan dan pemberantasan DBD, maka sebaiknya kegiatan PSN dilakukan secara terus menerus dan dipantau secara teratur melalui kegitan Pemantauan Jentik Berkala yang dilakukan oleh petugas sanitasi puskesmas dan tenaga terlatih. Perlu ditingkatkan juga penyuluhan mengenai PSN DBD kepada semua kalangan masyarakat dapat ikut perpartisipasi aktif dalam kegiatan PSN dan tidak hanya dilakukan dengan 3M tetapi juga dengan metode lain (larvasida, memelihara ikan predator jentik, fogging dll).

\section{SIMPULAN DAN SARAN}

\section{A. Kesimpulan}

Berdasarkan hasil penelitian diatas dapat disimpulkan bahwa :

1. Jumlah Rumah Positif Jentik di wilayah UPT Kesmas Blahbatuh I adalah 16 rumah dimana desa yang paling banyak terdapat jentik adalah di desa Keramas dan Pering yaitu masing-masing 4 rumah.

2. Niai CI yang didapatkan adalah 8 $\%$. Diketahui jumlah container yang positif jentik adalah 16 container dari 201 kontainer yang diperiksa.

3. Nilai bruteu indeks di Wilayah Kerja UPT Kesmas Blahbatuh I adalah $16 \%$.

4. Didapatkan angka bebas jentik di wilayah kerja UPT Kesmas Blahbatuh I adalah 84\%. Hal ini termasuk Wilayah Beresiko.

5. Didapatkan nilai Density Figure / Tingkat Kepadatan Jentik Nyamuk di Wilayah Kerja UPT Kesmas Blahbatuh I berada pada nilai 3 yang berarti wilayah memiliki Kepadatan Sedang. 


\section{B. Saran}

Berdasarkan penelitian yang telah dilakukan dapat disarankan sebagai berikut :

1. Kepada UPT Kesmas Blahbatuh I Agar lebih rutin melakukan kegiatan PSN/ Pemberantasan sarang Nyamuk serta melakukan pengawasan terhadap kegiatan PSN yang telah dilakukan. Agar dapat membentuk Jumantik mandiri disetiap rumah agar memudahkan pemantauan jentik serta PSN yang akan dilakukan.

2. Kepada Masyarakat

Agar ikut serta dalam kegiatan PSN ataupun menjaga kebersihan lingkungan rumah agar tidak terjadi penularan demam berdarah dengue, serta tidak menggantung baju dalam kamar agar tidak menjadi tempat perindukan nyamuk aedes aegypty.
4. Lestari E. Kepadatan Jentik Vektor Demam Berdarah Dengue (DBD) Aedes sp. Di Daerah Endemis, Seporadis dan Potensial Kota Semarang, Provinsi Jawa Tengah. Balaba, , 71-76. 2014; Vol 10. No.

5. Santoso Y. Analisis Kejadian Luar Biasa (KLB) Demam Berdarah Dengue (DBD) di Wilayah Puskesmas Rawasari Kota Jambi Bulan Agustus 2011. Ekologi Kesehatan. 2011;Vol. 10 No:248-55.

6. Gama.Z.P et all. Strategi Pemberantasan Nyamuk Aman Lingkungan :Potensi Bacillus turingiensis Isolat Madura Sebagai Musuh Alami Nyamuk Aedes aegypti. Pembangunan Dan Alam ,. 2010;Lestari.Vo:2087-3522.

7. Prasetyowati R d. Maya Indeks dan Kepadatan Larva Aedes Aegypty Di Daerah Endemis Jakarta Timur. Vektora. 2017; Vol 9 No 1:41-9.

\section{DAFTAR PUSTAKA}

1. RI K. Pencegahan dan Pemberantasan Demam Berdarah Dengue. Jakarta; 2011.

2. Dinkes. Profil Kesehatan Kabupaten Gianyar Tahun 2016. Gianyar; 2017.

3. Notoatmodjo. Metodologi Penelitian Kesehatan. Jakarta: PT Rineka Cipta.; 2012. 